UDC 666.117 .2

\author{
V.I. Goleus, Yu.S. Hordieiev, A.V. Nosenko
}

\title{
EFFECT OF THE MELTING CONDITIONS ON THE PROPERTIES OF GLASSES IN THE SYSTEM PbO- $\mathrm{ZnO}_{-} \mathrm{B}_{2} \mathrm{O}_{3}-\mathrm{SiO}_{2}$
}

\author{
Ukrainian State University of Chemical Technology, Dnipro, Ukraine
}

\begin{abstract}
Oxide system $\mathrm{PbO}-\mathrm{ZnO}-\mathrm{B}_{2} \mathrm{O}_{3}-\mathrm{SiO}_{2}$ with the content of lead oxide of more than 45 mol.\% is the basis of non-crystallizable low-melting glasses with softening temperature of lower than $450^{\circ} \mathrm{C}$. Lead-containing glasses are very aggressive, therefore they are melted in the platinum crucibles or ceramic crucibles which are resistant to the aggressive action of the lead glass melt. During the process of the melting of lead glasses in ceramic crucibles, the additives $\left(\mathrm{Al}_{2} \mathrm{O}_{3}\right.$ and $\left.\mathrm{SiO}_{2}\right)$ are transferred from the crucible to the glass melt. An uncontrolled amount of these additives affects the properties of the glasses. The objective of this work was to establish the effect of the temperature-time conditions of melting on the physical and chemical properties of high-lead glasses prepared in both platinum crucibles and ceramic ones. The results of the study showed significant difference in properties of glasses synthesized in crucibles fabricated from different materials. Glass synthesized in the platinum crucible under various temperature-time conditions was characterized by stable physical and chemical characteristics and low softening temperature $\left(\sim 380^{\circ} \mathrm{C}\right)$ without any traces of crystallization under repeated heat treatment. The melting in the alumina crucible and quartz crucible under the same temperature-time conditions resulted in both a decrease in physical and chemical characteristics of low-melting glass and an increase in the glass softening temperature to $450-470^{\circ} \mathrm{C}$ due to crystallization of glass during a heat treatment.
\end{abstract}

Keywords: glass, glass frits, low-melting glass, platinum crucible, softening temperature, lead glass.

DOI: $10.32434 / 0321-4095-2019-127-6-47-52$

\section{Introduction}

Glass frits with softening temperatures below $420-450^{\circ} \mathrm{C}$ are currently used for sealing of semiconductor micro-electronic devices. The oxide system $\mathrm{PbO}-\mathrm{ZnO}-\mathrm{B}_{2} \mathrm{O}_{3}-\mathrm{SiO}_{2}$ with the content of $\mathrm{PbO}$ of more than $45 \mathrm{~mol} \%$ is the basis of compositions of such low-melting glasses [1,2]. It should be noted that high-lead glasses melts are characterized by increased aggressivity towards the material of crucible where they are synthesized. Therefore, the melting of such glasses is commonly carried out in platinum, quartz or alumina crucibles, which are weekly subjected to the destructive action of high-lead glass-forming melts.

Among the above-mentioned crucibles, the crucibles made of expensive platinum are most resistant to the aggressive action of melts. Ceramic crucibles are cheaper and, accordingly, more affordable than the platinum ones. However, the use of such crucibles involves the transfer of trace components $\left(\mathrm{Al}_{2} \mathrm{O}_{3}, \mathrm{SiO}_{2}\right.$, etc. $)$ to the glass-forming melt. An uncontrolled amount of these components considerably affects the properties of the glass. The amount of the above-mentioned oxides, which can be transferred to the melt, significantly depends on the glass composition and temperature-time conditions of its melting [3-5].

In connection with this, the objective of this work was to establish the effect of the temperaturetime conditions of melting on the physical and chemical properties of high-lead glasses obtained in both platinum crucibles and ceramic ones.

\section{Materials and methods}

The chemical compositions of the glasses under study are shown in Table 1. For the preparation of glass mixtures, fine-grained quartz sand and chemical reagents of «chemically pure» and «analytically pure» grades $\left(\mathrm{H}_{3} \mathrm{BO}_{3}, \mathrm{ZnO}\right.$ and $\left.\mathrm{Pb}_{3} \mathrm{O}_{4}\right)$ were used. Glass 
was melted in the platinum, alumina and quartz crucibles $(30-50 \mathrm{~mL})$ in the electric furnace with silicon carbide heaters at the temperature of $850^{\circ} \mathrm{C}$ during 30 minutes.

Table 1

Chemical composition of glass

\begin{tabular}{c|c|c|c|c}
\hline \multirow{2}{*}{ Glass No. } & \multicolumn{4}{|c}{ Content, $\mathrm{mol}^{\circ} \%$} \\
\cline { 2 - 5 } & $\mathrm{PbO}$ & $\mathrm{ZnO}$ & $\mathrm{B}_{2} \mathrm{O}_{3}$ & $\mathrm{SiO}_{2}$ \\
\hline 1 & 55 & 20 & 20 & 5 \\
\hline 2 & 55 & 15 & 25 & 5 \\
\hline 3 & 55 & 10 & 30 & 5 \\
\hline 4 & 55 & 5 & 35 & 5 \\
\hline 5 & 55 & 15 & 20 & 10 \\
\hline 6 & 55 & 10 & 25 & 10 \\
\hline 7 & 55 & 5 & 30 & 10 \\
\hline 8 & 55 & 15 & 15 & 15 \\
\hline 9 & 55 & 10 & 20 & 15 \\
\hline 10 & 55 & 5 & 25 & 15 \\
\hline 11 & 55 & 5 & 20 & 20 \\
\hline
\end{tabular}

The samples of glasses for determination of their properties were produced by the method of casting of glass melt into steel molds with the subsequent annealing in the muffle furnace at the temperature of $250^{\circ} \mathrm{C}$.

The properties of glass were determined by the standard procedures as follows: density (d) of glasses by hydrostatic weighing as per GOST 9553-74; coefficient of linear thermal expansion (CLTE) in the temperature range of $20-200^{\circ} \mathrm{C}$ and dilatometric softening temperature $(\mathrm{Mg})$ with the use of quartz dilatometer in accordance with GOST 10978-2014.

$\mathrm{X}$-ray phase analysis of glasses was carried out using a diffractometer DRON-3M in $\mathrm{Co}-\mathrm{K}_{\alpha}$ radiation. For this purpose, the samples of glasses powders were formed by means of semi-dry molding, sintered and the resulting sintered material was further ground in the agate mortar to pass through the sieve No. 0063 . To identify crystalline phases, X-ray card index of ASTM [6] was used.

Study of the crystallization ability of glass powders was conducted by the method of differential and thermal analysis using a derivatograph Q-1500 D in the temperature range of $20-600^{\circ} \mathrm{C}$ at the heating rate of $5^{\circ} \mathrm{C} / \mathrm{min}$. Powders obtained by crushing of glass in the agate mortar were used to evaluate dispersion by passing through the sieve No. 0063 .

\section{Results and discussion}

Some properties of glasses under study are given in Table 2. This Table shows that the values of properties of glasses synthesized under the same temperature-time conditions in crucibles of different materials differ substantially.

Glasses synthesized in the platinum crucible, as distinct from glasses synthesized in the alumina and quartz crucibles, are characterized by low values of dilatometric temperature of the start of softening, and high values of CLTE and density.

The above suggests that glass-forming melts actively interact with the surface of ceramic crucibles during the melting of experimental glasses. Because of this interaction, a substantial amount of impurities $\mathrm{Al}_{2} \mathrm{O}_{3}$ and $\mathrm{SiO}_{2}$ are carried to the composition of glasses.

Table 2

Physical and chemical properties of glasses melted in the platinum (1), alumina (2) and quartz (3) crucibles

\begin{tabular}{c|c|c|c|c|c|c|c|c|c}
\hline \multirow{2}{*}{$\begin{array}{c}\text { Glass } \\
\text { No. }\end{array}$} & \multicolumn{3}{|c|}{$\mathrm{Mg},{ }^{0} \mathrm{C}$} & \multicolumn{3}{c|}{$\begin{array}{c}\text { CLTE, } \\
\alpha \cdot 10^{7}, \mathrm{~K}^{-1}\end{array}$} & \multicolumn{3}{c}{$\begin{array}{c}\text { Density, } \\
\text { d, g/cm }\end{array}$} \\
\cline { 2 - 10 } & 1 & 2 & 3 & 1 & 2 & 3 & 1 & 2 & 3 \\
\hline 1 & 290 & 320 & 330 & 117 & 109 & 106 & 6.65 & 6.44 & 6.34 \\
\hline 2 & 300 & 325 & 340 & 115 & 107 & 105 & 6.50 & 6.28 & 6.21 \\
\hline 3 & 310 & 330 & 350 & 111 & 106 & 103 & 6.35 & 6.12 & 6.08 \\
\hline 4 & 325 & 340 & 360 & 109 & 105 & 102 & 6.19 & 5.95 & 5.94 \\
\hline 5 & 310 & 325 & 340 & 111 & 105 & 105 & 6.53 & 6.33 & 6.25 \\
\hline 6 & 320 & 330 & 350 & 110 & 104 & 102 & 6.38 & 6.17 & 6.12 \\
\hline 7 & 330 & 340 & 360 & 107 & 103 & 102 & 6.20 & 6.03 & 6.00 \\
\hline 8 & 315 & 330 & 350 & 108 & 106 & 105 & 6.62 & 6.45 & 6.36 \\
\hline 9 & 325 & 340 & 360 & 107 & 103 & 102 & 6.46 & 6.28 & 6.22 \\
\hline 10 & 335 & 350 & 365 & 105 & 101 & 97 & 6.30 & 6.12 & 6.08 \\
\hline 11 & 340 & 360 & 370 & 103 & 99 & 95 & 6.30 & 6.14 & 6.10 \\
\hline
\end{tabular}

The effect of the initial composition of glassforming melt on the degree of its aggressivity with regard to the material of ceramic crucible can be assessed based on the data given in Fig. 1. In this case, the glass melt aggressivity $(\Delta \mathrm{d})$ was determined by changing the density of glasses $\left(\mathrm{d}_{\mathrm{k}}\right)$ prepared in the ceramic crucibles with regard to density of glasses $\left(d_{p}\right)$ synthesized in the platinum crucible, $(\%)$ : $\Delta d=\left(d_{p}-d_{k}\right) \cdot 100 / d_{k}$.

In the process of melting in the alumina crucible, the aggressivity of glass melt grows considerably when $\mathrm{SiO}_{2}$ is replaced by $\mathrm{B}_{2} \mathrm{O}_{3}$ (Fig. 1,a). An increase in the content of $\mathrm{B}_{2} \mathrm{O}_{3}$ from 25 to $40 \mathrm{~mol} . \%$ leads to a decrease in the glass density from 2.6 to $4.0 \%$ owing to $\mathrm{SiO}_{2}$ reduction. With the use of the melting in the quartz crucible, the aggressivity of glass melt increases appreciably with the replacement of $\mathrm{SiO}_{2}$ by $\mathrm{ZnO}$ (Fig. 1,b). An increase in the $\mathrm{ZnO}$ content from 5 to $20 \mathrm{~mol} . \%$ results in a decrease in the glass density from 3.2 to $5.0 \%$ owing to $\mathrm{SiO}_{2}$ reduction.

Figure 1 shows that the aggressivity of the melt 

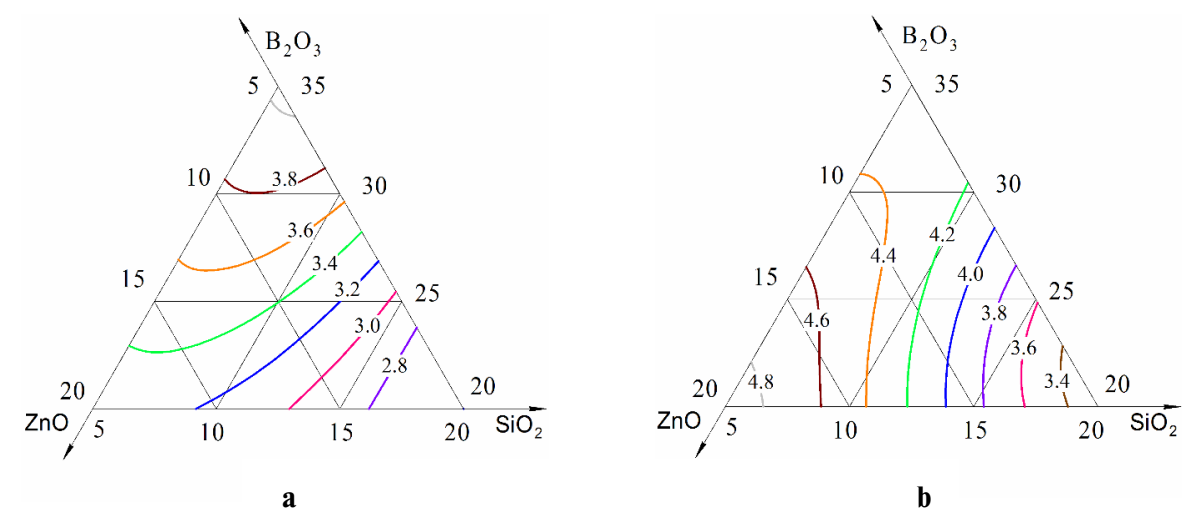

Fig. 1. Density of the glasses synthesized in the alumina (a) and quartz (b) crucibles as a function of their chemical composition

towards the material of the ceramic crucible becomes lower with an increase in $\mathrm{SiO}_{2}$ content in the glass composition, which is obviously related to an increase in the viscosity of glass melt during melting process. This is clearly seen from the dependence of $\mathrm{Mg}$, characterizing the viscosity of the glass in the area of its softening, on the chemical composition of the glass (Fig. 2). An increase in the content of $\mathrm{SiO}_{2}$ from 5 to $20 \mathrm{~mol} \%$ results in an increase in the values of $\mathrm{Mg}$ of the glass from 290 to $340^{\circ} \mathrm{C}$.

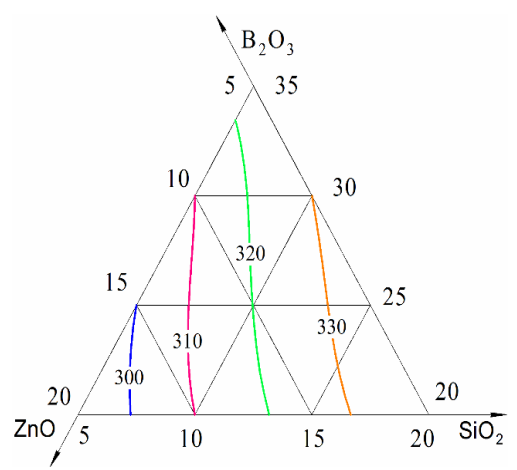

Fig. 2. Values of $\mathrm{Mg}$ of the glasses synthesized in the platinum crucible as a function of their chemical composition

Along with the marked impact of impurities $\mathrm{Al}_{2} \mathrm{O}_{3}$ and $\mathrm{SiO}_{2}$ on the values of $\mathrm{Mg}, \mathrm{CLTE}$ and $\mathrm{d}$ of the glasses, these additives may also affect the crystallization ability of the glasses. Therefore, the crystallization ability of powders of the glass No. 7 was investigated using DTA method. Let us note that according to data given in work [1], this glass is the most promising one for obtaining of metal-toceramic seals at the temperature below $450^{\circ} \mathrm{C}$ (Fig. 3 ). The glass of the above-mentioned composition melted in the platinum crucible at the heating up to $500^{\circ} \mathrm{C}$ was characterized by the least crystallization ability (Fig. 3,a) and, as a consequence, its melt well spreaded over the surface of aluminium-oxide ceramics. The glasses melted in the alumina and quartz crucibles are characterized by a higher crystallization ability which is proved by exothermic peaks at $410-420^{\circ} \mathrm{C}$ (Fig. 3,b and $3, \mathrm{c}$ ) and $515^{\circ} \mathrm{C}$ (Fig. 3,c).

The crystallization of glass commonly reduces the glass melt spreadability. Hence, it can be assumed that the most suitable temperature for the preparation of metal-to-ceramic seals based on the glasses synthesized in the alumina and quartz crucibles is no more than $450^{\circ} \mathrm{C}$.

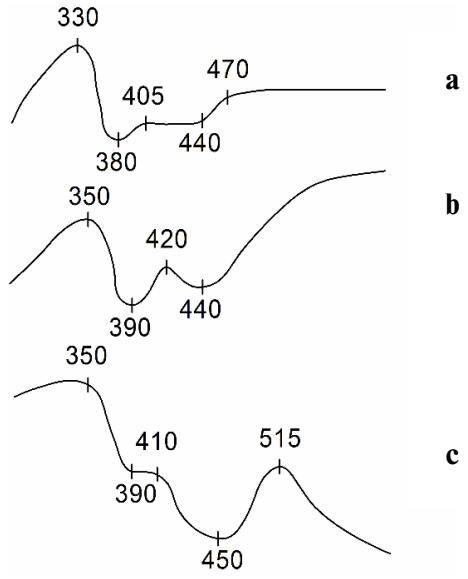

Fig. 3. Thermographs of powders of the glass No. 7 synthesized in the platinum (a), quartz (b) and alumina (c) crucibles during 30 minutes at $850^{\circ} \mathrm{C}$

It is known [3] that the amount of impurities $\mathrm{Al}_{2} \mathrm{O}_{3}$ and $\mathrm{SiO}_{2}$, which can be transferred to the glass melt due to its interaction with the stuff of ceramic crucible depends not only on the chemical composition of glass, but also on the duration $(\tau)$ and on temperature $(\mathrm{t})$ of the melting process. In this regard, the effects of temperature and duration of melting of the glass No. 7 on its properties was determined (Tables 3 and 4). 
Table 3

Effect of melting temperature $(\tau=30 \mathrm{~min})$ on the physical and chemical properties of the glass No. 7 prepared in the platinum (1), alumina (2) and quartz (3) crucibles

\begin{tabular}{c|c|c|c|c|c|c|c|c|c}
\hline \multirow{2}{*}{$\mathrm{t},{ }^{0}$} & \multicolumn{3}{|c|}{$\mathrm{Mg},{ }^{0} \mathrm{C}$} & \multicolumn{3}{c|}{$\begin{array}{c}\text { CLTE, } \\
\alpha \cdot 10^{7}, \mathrm{~K}^{-1}\end{array}$} & \multicolumn{3}{c}{$\begin{array}{c}\text { Density, } \\
\mathrm{d}, \mathrm{g} / \mathrm{cm}^{3}\end{array}$} \\
\cline { 2 - 11 } & 1 & 2 & 3 & 1 & 2 & 3 & 1 & 2 & 3 \\
\hline 850 & 330 & 340 & 360 & 107 & 103 & 102 & 6,20 & 6.03 & 6,00 \\
\hline 900 & 330 & 350 & 370 & 107 & 98 & 98 & 6,20 & 5.79 & 5.93 \\
\hline 950 & 330 & 360 & 375 & 107 & 97 & 96 & 6,20 & 5.72 & 5.88 \\
\hline
\end{tabular}

Table 4

Effect of melting duration $\left(t=850^{\circ} \mathrm{C}\right)$ on the physical and chemical properties of the glass No. 7 prepared in the platinum (1), alumina (2) and quartz (3) crucibles

\begin{tabular}{c|c|c|c|c|c|c|c|c|c}
\hline \multirow{2}{*}{$\begin{array}{c}\tau, \\
\min \end{array}$} & \multicolumn{3}{|c|}{$\mathrm{Mg},{ }^{0} \mathrm{C}$} & \multicolumn{3}{c|}{$\begin{array}{c}\text { CLTE, } \\
\alpha \cdot 10^{7}, \mathrm{~K}^{-1}\end{array}$} & \multicolumn{3}{c}{$\begin{array}{c}\text { Density, } \\
\mathrm{d}, \mathrm{g} / \mathrm{cm}^{3}\end{array}$} \\
\cline { 2 - 11 } & 1 & 2 & 3 & 1 & 2 & 3 & 1 & 2 & 3 \\
\hline 30 & 330 & 340 & 360 & 107 & 103 & 102 & 6.20 & 6.03 & 6.00 \\
\hline 60 & 330 & 350 & 360 & 107 & 102 & 101 & 6.20 & 5.96 & 5.97 \\
\hline 90 & 330 & 360 & 365 & 107 & 99 & 99 & 6.20 & 5.87 & 5.95 \\
\hline 120 & 330 & 365 & 370 & 107 & 97 & 95 & 6.20 & 5.72 & 5.90 \\
\hline
\end{tabular}

One can easily see that the change of temperature-time conditions of the melting of the glass No. 7 in the platinum crucible has no effect on its properties. However, an increase in the temperature and duration of melting of the glass No. 7 promotes an active interaction of its melt with the surface of the alumina and quartz crucibles and, accordingly, a substantial change in its properties as compared with the properties of the glass melted in the platinum crucible. The reduction of temperature of the glass melting to $800^{\circ} \mathrm{C}$ leads to an increase in the viscosity of the glass melt and in the time of melting from 30 to 60 minutes. As a result, the melts of glasses synthesized in the alumina and quartz crucibles at the temperature of $800^{\circ} \mathrm{C}$ were crystallized in the process of casting.

Consequently, one can conclude that in order to prepare a glass with a minimal content of impurities $\left(\mathrm{Al}_{2} \mathrm{O}_{3}\right.$ and $\left.\mathrm{SiO}_{2}\right)$ the process of melting should be performed at a relatively moderate temperature (no more than $850^{\circ} \mathrm{C}$ ) and, if possible, for the short period of time (but not less than 30 minutes).

The temperature-time conditions of melting of the experimental glass also have a strong effect on its crystallization ability (Figs. 4 and 5).

With an increase in the duration of synthesis in the quartz crucible from 30 minutes (Fig. 3,b) to 120 minutes (Fig. 4,b), the reduction of crystallization intensity at $420^{\circ} \mathrm{C}$ is observed that follows from a decrease in exothermic peak height. An increase in the time of melting in the alumina crucible from 30 minutes (Fig. 3,c) to 120 minutes (Fig. 4,c) causes its crystallization during the heat treatment in the temperature interval of $410-460^{\circ} \mathrm{C}$, thus shifting the softening temperature of glass to $470^{\circ} \mathrm{C}$.
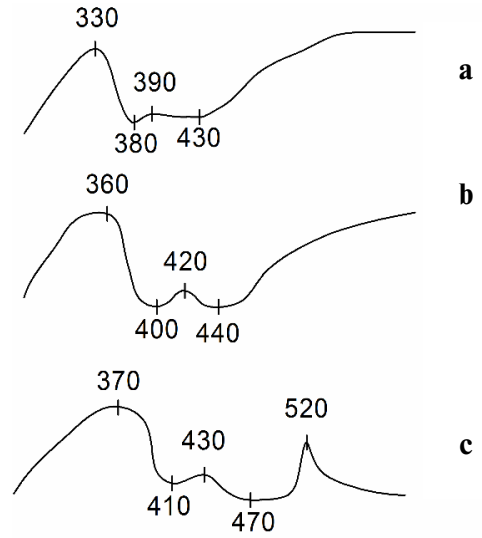

Fig. 4. Thermographs of powders of the glass synthesized in the platinum (a), quartz (b) and alumina (c) crucibles during 120 minutes at $850^{\circ} \mathrm{C}$

$\mathrm{X}$-ray phase analysis allowed determining the main crystalline phases, which are formed in the process of heat treatment of the glass No. 7 synthesized in the alumina crucible. X-ray patterns (Fig. 5) of the products of the glass heat treatment show that one crystalline phase, $\mathrm{PbO}(\mathrm{d}=3.08 ; 2.82$; 1.87 ) is formed in the process of crystallization of the glass at the temperature of $430^{\circ} \mathrm{C}$ (Fig. 5,a). When the temperature of the heat treatment is increased to $520^{\circ} \mathrm{C}$, the amount of a crystalline phase of $\mathrm{PbO}$ grows that follows from an increase in the intensity of diffraction maximums in the X-ray patterns (Fig. $5, b)$.

\section{Conclusions}

The obtained experimental results showed the effects of the chemical composition and temperaturetime conditions of the glass melting in the platinum, alumina and quartz crucibles on the physical and chemical properties of low-melting glasses in the oxide system $\mathrm{PbO}-\mathrm{ZnO}-\mathrm{B}_{2} \mathrm{O}_{3}-\mathrm{SiO}_{2}$ with the $\mathrm{PbO}$ content of $55 \mathrm{~mol} \%$. It was found that the glass synthesized in the platinim crucible under different temperature-time conditions featured stable physical and chemical characteristics and low softening temperature $\left(\sim 380^{\circ} \mathrm{C}\right)$ without any traces of crystallization after the heat treatment. It was shown that the melting in the alumina and quartz crucibles under the same conditions leads to the deterioration 

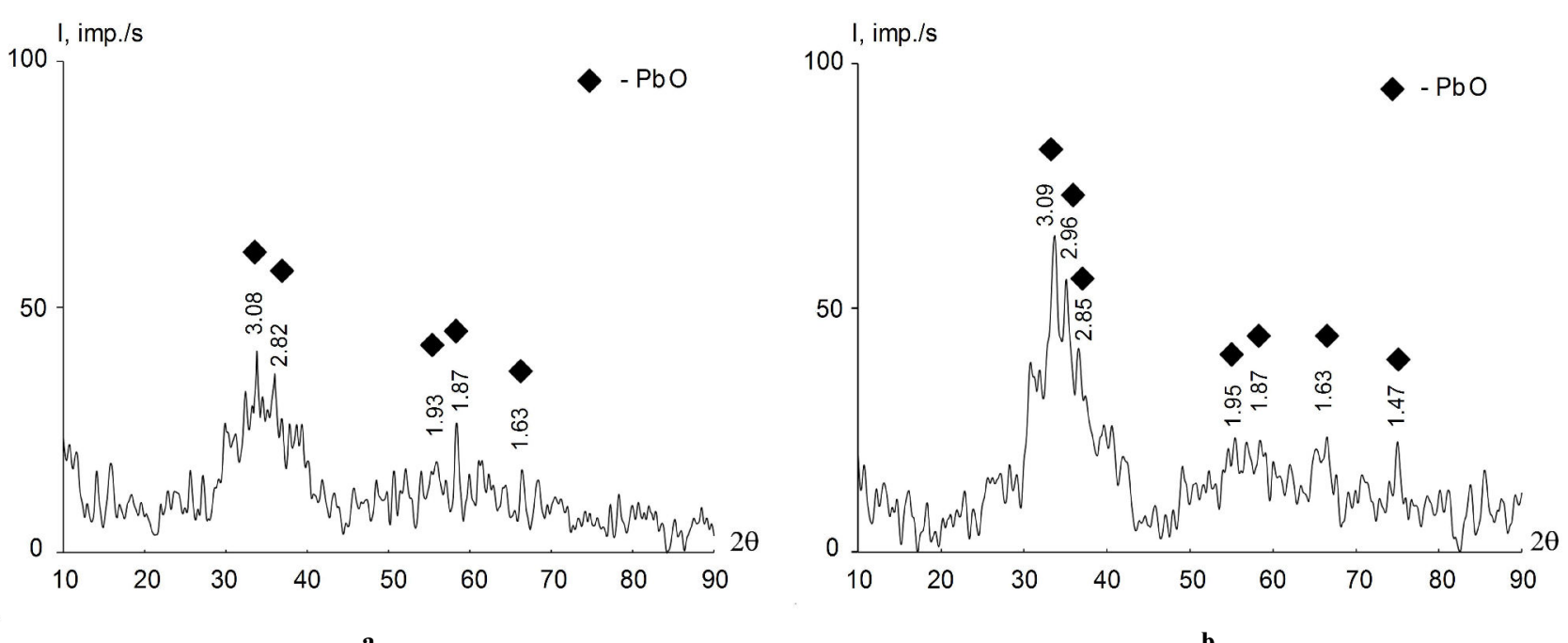

a

Fig. 5. X-ray diffraction patterns of the glass powder after the heat treatment at $430^{\circ} \mathrm{C}$ (a) and $520^{\circ} \mathrm{C}$ (b) during 1 hour

of physical and chemical characteristics of lowmelting glass and to an increase in the temperature of glass softening to $450-470^{\circ} \mathrm{C}$ due to its crystallization during the heat treatment.

\section{REFERENCES}

1. Goleus V.I., Hordieiev Y.S., Nosenko A.V. Vlastyvosti legkoplavkykh stekol v systemi $\mathrm{PbO}-\mathrm{ZnO}-\mathrm{B}_{2} \mathrm{O}_{3}-\mathrm{SiO}_{2} / /$ Voprosy Khimii i Khimicheskoi Tekhnologii. - 2018. - No. 4. - P.9296.

2. Investigation of the possibility of replacing high-lead glasses in fusible glass solders by less toxic glasses / D.A. Geodakyan, B.V. Petrosyan, S.V. Stepanyan, K.D. Geodakyan // Glass and Ceramics. - 2009. - Vol.66. P.381-384.

3. Ceramic crucibles: a new alternative for melting of $\mathrm{PbO}-\mathrm{BiO}_{1.5}-\mathrm{GaO}_{1.5}$ glasses / dos Santos I.M.G., Moreira R.C.M., de Souza A.G., Lebullenger R., Hernandes A.C., Leite E.R., Paskocimas C.A., Longo E. // J. Non-Cryst. Solids. - 2003. Vol.319. - P.304-310.

4. Ceramic crucible corrosion by heavy metal oxide glasses, part I: phenomenological study / dos Santos I.M.G., Moreira R.C.M., de Souza A.G., Paskocimas C.A., Leite E.R., Varela J.A., Longo E. // InterCeram: Int. Ceram. Rev. - 2003. - Vol.52. - No. 4. P.198-205.

5. Influence of the melting conditions of heavy metal oxide glasses containing bismuth oxide on their optical absorption / O. Sanz, E. Haro-Poniatowski, J. Gonzalo, J.M. Fernandez Navarro // J. Non-Cryst. Solids. - 2006. - Vol.352. - P.761768.

6. Index of the X-ray powder. - Philadelphia: American Society for Testing and Materials (ASTM). - 1967.

Received 04.06.2019

\section{ВПЛИВ УМОВ ВАРІННЯ НА ВЛАСТИВОСТІ СТЕКОЛ В} CИСТЕМI $\mathrm{PbO}-\mathrm{ZnO}-\mathrm{B}_{2} \mathrm{O}_{3}-\mathrm{SiO}_{2}$

\section{В.І. Голеус, Ю.С. Гордєєв, О.В. Носенко}

В основі складів легкоплавких стекол, що не кристалізуються, з температурами розм'якшення нижие $450^{\circ} \mathrm{C}$ лежить оксидна система $\mathrm{PbO}-\mathrm{ZnO}-\mathrm{B}_{2} \mathrm{O}_{3}-\mathrm{SiO}_{2}$ із вмістом оксиду плюмбуму більше 45 мол.\%. Плюмбумвмісні стекла дуже агресивні, тому їх варіння здійснюють у платинових або керамічних тиглях, які стійкі до агресивної дії розплаву свинцевого скла. У процесі варіння свинцевих стекол в керамічних тиглях в розплав скла з тигля переходять добавки $\left(\mathrm{Al}_{2} \mathrm{O}_{3}, \mathrm{SiO}_{2}\right)$, неконтрольована кількість яких впливає на властивості стекол. Метою цієї роботи було встановити вплив температурно-часових умов варіння на фізико-хімічні властивості багатосвинцевих стекол одержаних як в платинових, так $і$ в керамічних тиглях. Здійснені дослідження показали суттєву відмінність у властивостях стекол, синтезованих у тиглях з різних матеріалів. Скло, синтезоване в платиновому тиглі при різних температурно-часових умовах, характеризувалося стабільними фізико-хімічними характеристиками та низькою температурою розм'якшення $\left(\sim 380^{\circ} \mathrm{C}\right)$ без слідів кристалізації при повторному термічному обробленні. Варка в корундовому та квариовому тиглях в тих же температурно-часових умовах призводить до зниження фізико-хімічних характеристик легкоплавкого скла та збільшення температури розм'якшення скла до $450-470^{\circ} \mathrm{C}$ внаслідок його кристалізації при термічному обробленні.

Ключові слова: скло, склоприпій, легкоплавке скло, платиновий тигель, температура розм'якшення, свинцеве скло.

Effect of the melting conditions on the properties of glasses in the system $\mathrm{PbO}-\mathrm{ZnO}-\mathrm{B}_{2} \mathrm{O}_{3}-\mathrm{SiO}_{2}$ 


\section{EFFECT OF THE MELTING CONDITIONS ON THE PROPERTIES OF GLASSES IN THE SYSTEM $\mathrm{PbO}-\mathrm{ZnO}-\mathrm{B}_{2} \mathrm{O}_{3}-\mathrm{SiO}_{2}$}

\section{V.I. Goleus ", Y.S. Hordieiev, A.V. Nosenko}

Ukrainian State University of Chemical Technology, Dnipro, Ukraine

* e-mail: holvik22@gmail.com

Oxide system $\mathrm{PbO}-\mathrm{ZnO}-\mathrm{B}_{2} \mathrm{O}_{3}-\mathrm{SiO}_{2}$ with the content of lead oxide of more than $45 \mathrm{~mol} . \%$ is the basis of non-crystallizable lowmelting glasses with softening temperature of lower than $450^{\circ} \mathrm{C}$. Leadcontaining glasses are very aggressive, therefore they are melted in the platinum crucibles or ceramic crucibles which are resistant to the aggressive action of the lead glass melt. During the process of the melting of lead glasses in ceramic crucibles, the additives $\left(\mathrm{Al}_{2} \mathrm{O}_{3}\right.$ and $\mathrm{SiO}_{2}$ ) are transferred from the crucible to the glass melt. An uncontrolled amount of these additives affects the properties of the glasses. The objective of this work was to establish the effect of the temperature-time conditions of melting on the physical and chemical properties of high-lead glasses prepared in both platinum crucibles and ceramic ones. The results of the study showed significant difference in properties of glasses synthesized in crucibles fabricated from different materials. Glass synthesized in the platinum crucible under various temperature-time conditions was characterized by stable physical and chemical characteristics and low softening temperature $\left(\sim 380^{\circ} \mathrm{C}\right)$ without any traces of crystallization under repeated heat treatment. The melting in the alumina crucible and quartz crucible under the same temperature-time conditions resulted in both a decrease in physical and chemical characteristics of low-melting glass and an increase in the glass softening temperature to $450-470^{\circ} \mathrm{C}$ due to crystallization of glass during a heat treatment.

Keywords: glass; glass frits; low-melting glass; platinum crucible; softening temperature; lead glass.

\section{REFERENCES}

1. Goleus V.I., Hordieiev Y.S., Nosenko A.V. Vlastyvosti legkoplavkyh stekol v systemi $\mathrm{PbO}-\mathrm{ZnO}-\mathrm{B}_{2} \mathrm{O}_{3}-\mathrm{SiO}_{2}$ [Properties of low-melting glasses in the system $\mathrm{PbO}-\mathrm{ZnO}-\mathrm{B}_{2} \mathrm{O}_{3}-\mathrm{SiO}_{2}$ ] Voprosy Khimii i Khimicheskoi Tekhnologii, 2018, no. 4, pp. 9296. (in Ukrainian).

2. Geodakyan D.A., Petrosyan B.V., Stepanyan S.V., Geodakyan K.D. Investigation of the possibility of replacing highlead glasses in fusible glass solders by less toxic glasses. Glass and Ceramics, 2009, vol. 66, pp. 381-384.

3. dos Santos I.M.G., Moreira R.C.M., de Souza A.G., Lebullenger R., Hernandes A.C., Leite E.R., Paskocimas C.A., Longo E. Ceramic crucibles: a new alternative for melting of $\mathrm{PbO}-\mathrm{BiO}_{1.5}-\mathrm{GaO}_{1.5}$ glasses. Journal of Non-Crystalline Solids, 2003, vol. 319, pp. 304-310.

4. dos Santos I.M.G., Moreira R.C.M., de Souza A.G., Paskocimas C.A., Leite E.R., Varela J.A., Longo E. Ceramic crucible corrosion by heavy metal oxide glasses, part I: phenomenological study. InterCeram: International Ceramic Review, 2003, vol. 52, no. 4, pp. 198-205.

5. Sanz O., Haro-Poniatowski E, Gonzalo J., Fernandez Navarro J.M. Influence of the melting conditions of heavy metal oxide glasses containing bismuth oxide on their optical absorption. Journal of Non-Crystalline Solids, 2006, vol. 352, pp. 761-768.

6. Index of the X-ray powder. American Society for Testing and Materials (ASTM). Philadelphia, 1967. 